\title{
Nematode infection patterns in a Neotropical lizard species from an insular mountain habitat in Brazil
}

\author{
A.B.H.P. Václav ${ }^{1,3}$, L.A. Anjos ${ }^{2}$, M.S. Queiróz ${ }^{2}$, L.B. Nascimento ${ }^{3}$ \\ and C.A.B. Galdino ${ }^{3 *}$ \\ ${ }^{1}$ PET Biologia PUC Minas - MEC/SESu, Pontifícia Universidade Católica \\ de Minas Gerais, 30535-901, Belo Horizonte, Brazil: ${ }^{2}$ Departamento de \\ Biologia e Zootecnia, Laboratório de Parasitologia e Zoologia, UNESP, \\ Universidade Estadual Paulista, FEIS, Passeio Monção 226, CEP 15385-000, \\ Ilha Solteira, Brazil: ${ }^{3}$ Programa de Pós-graduação em Biologia de \\ Vertebrados, Pontifícia Universidade Católica de Minas Gerais, 30535-610, \\ Belo Horizonte, Brazil
}

(Received 12 July 2016; Accepted 27 September 2016; First published online 28 October 2016)

\begin{abstract}
Neotropical lizards are known to harbour rich nematode parasite faunas; however, knowledge of the diversity and patterns of infection are still lacking for many species. This is true for the genus Tropidurus, in which data on patterns of parasitism are known for only approximately 11 of its 30 species. We show that the nematode fauna associated with a population of Tropidurus montanus is composed of three species of host-generalist parasites with high overall prevalence. Male and female lizards did not differ in infection pattern and there was no relationship between host body size and intensity of infection for the most prevalent parasite species. Nevertheless, overall prevalence changed seasonally, with a higher proportion of parasitized individuals being found in the dry period than in the rainy period. We discuss our findings in the context of diet patterns of T. montanus, which we suggest may explain the similarities in prevalence and intensity of infection between the sexes. In addition, seasonal changes in diet are considered to be related to the observed differences in prevalence between dry and rainy periods.
\end{abstract}

\section{Introduction}

The major climatic factor influencing ecological systems in the Neotropics is seasonal variation between dry and rainy periods. Changes in the amount of rain and in duration of the rainy period can affect patterns of infection spread and persistence (see Altizer et al., 2006). Therefore, parasitic interactions involving Neotropical species are expected to change over time in response to periodic

\footnotetext{
*E-mail: galdinoc@gmail.com

All authors consented to participation in the study and agreed upon the content of the article.
}

variation in rainfall, which can, in turn, result in seasonal patterns of infection. Lizards are ectotherms, thus adjusting their activity patterns and behaviours according to environmental conditions (e.g. Hatano et al., 2001; Filogonio et al., 2010), and so patterns of helminth infection can be expected to vary seasonally as well, reflecting the behavioural adjustments of these hosts (Ribas et al., 1995; Vrcibradic et al., 1999; Pereira et al., 2012; Brito et al., 2014).

Lizards are important components of the life cycle of many species of helminths, serving as definitive or intermediate hosts (e.g. Ávila \& Silva, 2010). The helminth fauna that parasitizes lizards is diverse and with varied patterns of infection. In this sense, helminth richness can vary geographically among populations (Brito et al., 
2014; Galdino et al., 2014), and changes in the composition of component communities can be unrelated to geographical distance among populations (Bezerra et al., 2016). Additionally, some studies have shown divergent results when considering whether infection rates and parasite loads of helminths vary between sexes, or whether parasite load is related to host body size. Hence, information is still needed for a more complete understanding of the epidemiological and ecological patterns of helminth infection in lizards.

The genus Tropidurus is speciose, with 30 species (Uetz \& Hošek, 2016). The genus harbours a rich helminth fauna with nearly 30 different parasite species and with component communities hosting from 3 to 21 species (Ávila \& Silva, 2010; Anjos et al., 2012). Recently, there have been efforts to uncover the diversity and patterns of helminth infection of species of Tropidurus (e.g. Tropidurus itambere, Ávila et al., 2011; T. hygomi and T. psammonastes, Lambertz et al., 2012; T. spinulosus, Lunaschi et al., 2012; T. torquatus, Pereira et al., 2012; T. oreadicus, Santos et al., 2013; T. hispidus and T. semitaeniatus, Brito et al., 2014); however, parasitological data are missing for approximately $60 \%$ of the species of the genus.

The occurrence of the lizard T. montanus is restricted to the rocky outcrop formations of the mountaintop habitats of the Serra do Espinhaço (Espinhaço mountain range) in South America (Rodrigues, 1987). To the best of our knowledge, information on parasitism of this species by helminths is lacking. The aim of the present study was to describe the helminth species composition and infection levels in the Neotropical lizard T. montanus, relative to seasonality, host sex and size.

\section{Materials and methods}

We conducted the study in the rocky outcrop formation at $c .1460 \mathrm{~m}$ above mean sea level in the Serra da Piedade (Piedade mountain range; $19^{\circ} 49^{\prime} \mathrm{S} ; 43^{\circ} 40^{\prime} \mathrm{W}$ ), a branch of the Espinhaço Range, in the state of Minas Gerais, Brazil. High-elevation open habitats of the mountains from eastern Brazil (which include the Espinhaço Range and related branches) are considered as isolated insular environments that play a role in biogeographical processes of plant and animal species (Chaves et al., 2015, Neves et al., 2016). The mean annual temperature is $21^{\circ} \mathrm{C}$ and the mean annual rainfall averages $1650 \mathrm{~mm}$. The region experiences a marked distinction between rainy (from October to March) and dry (from April to September) periods (Alvares et al., 2014).

Sampling of lizards took place during the rainy (December 2012) and dry months (June to August 2013). Lizards were sampled by performing visual encounter surveys throughout the period of activity of the species, and captured by noose or by shooting rubber bands. Captured lizards were killed by lethal injection of sodium thiopental, measured for body size (snout-to-vent length) with a Vernier caliper (nearest $0.1 \mathrm{~mm}$ ), fixed and preserved following standard procedures, and deposited in the herpetological collection of the Museu de Ciências Naturais of Pontifícia Universidade Católica de Minas Gerais (MCNR 4893-4934; 5114-5145; 5159-5174), Belo Horizonte, Brazil.
Post-mortem examinations of the body cavity, digestive tract, liver and lungs were undertaken using a stereomicroscope. Nematodes were cleared with Aman's lactophenol (Andrade, 2000) and analysed using a computerized system for image analysis LAS 5.0 (Leica Application Suite), adapted to a DM 2500-Leica microscope with a differential interference contrast system (Leica, Wetzlar, Germany). All the parasitological terms used followed Bush et al. (1997). Worms were deposited in the helminthological collection of the Instituto de Biociências de Botucatu, Universidade Estadual Paulista (species batches: CHIBB 7861; CHIBB 7862; CHIBB 7863), Botucatu, Brazil.

Differences between the sexes in overall helminth prevalence were tested by using the binomial test for each of the periods (rainy and dry). The binomial test was also used to test for differences in prevalence between the two periods, considering all individuals in a period regardless of sex. To evaluate the effects of period (dry and rainy) and sex on the overall intensity of helminth infection we used a two-way analysis of variance (ANOVA). Effects of body size on intensity of infection were evaluated for the helminth species with higher prevalence by conducting a Generalized Linear Mixed Models analysis considering each individual as a random effect variable. In addition, we used a one-factor permutation test to evaluate the effect of period on infection intensity of the more prevalent helminth species (Hothorn et al., 2008).

\section{Results}

The helminth component community of T. montanus ( $n=80$ ) was found to be composed of three species: Parapharyngodon alvarengai Freitas, 1957 (Pharyngodonidae) (prevalence $=59 \%$; mean intensity of infection $=5.6 \pm$ 5.1), found in both large and small intestines; Physaloptera sp. Rudolphi, 1819 (Physalopteridae) (prevalence $=12 \%$; mean intensity of infection $=4.9 \pm 8.2$ ), found in the larval stage in the stomach and large intestine, and Strongyluris oscari Travassos, 1923 (Heterakidae) (prevalence $=44 \%$; mean intensity of infection $=6.0 \pm 7.2$ ) found in lungs, large and small intestines. Therefore, $P$. alvarengai and $S$. oscari were the most prevalent nematodes found parasitizing individual lizards. Of the total of 80 lizards sampled, 64 were parasitized by at least one species, resulting in an overall prevalence of $80 \%$. Regarding infracommunities, $64 \%$ of lizards were parasitized by a single parasite species, while $30 \%$ of the hosts were parasitized by two and $6 \%$ by three species. Nematode abundance averaged $7.4 \pm 6.3$. The intensities of infection by $P$. alvarengai and by $S$. oscari were not related to host body size $(P=0.07, n=52$ and $P=0.60, n=50$, respectively).

We sampled 17 males and 20 females of T. montanus in the rainy period and 21 males and 22 females in the dry period. In the dry period, $95 \%$ of males and $100 \%$ of females were found to harbour helminths, with no difference in overall prevalence between the sexes $(P=0.98)$. During the rainy period, $70 \%$ of males and $50 \%$ of females were found to be parasitized and there was no difference in prevalence between males and females for the rainy period $(P=0.34)$. The population of $T$. montanus had higher overall prevalence during the dry period $(97 \%)$ than 
during the rainy period $(59 \%)(P<0.001)$. The overall intensity of helminth infection did not differ between seasons or between sexes (two-way ANOVA: $F=0.03$, $P=0.85)$. The intensity of infection by $P$. alvarengai and $S$. oscari did not vary between dry and rainy periods (onefactor permutation test, $Z=1.52, P=0.14$ and $Z=-1.18$, $P=0.26$, respectively).

\section{Discussion}

The nematode community parasitizing T. montanus was composed of three species. Of these, the nematode P. alvarengai (Pharyngodonidae) is known to infect other lizard species, including Ameiva ameiva (Padilha \& Duarte, 1979), Trachylepis atlantica (Ávila \& Silva, 2010), Hemidactylus agrius (Anjos et al., 2011), Urosaurus auriculatus (Goldberg \& Bursey, 2012), Tropidurus hispidus (Brito et al., 2014; Galdino et al., 2014) and Tropidurus semitaeniatus (Bezerra et al., 2015). The nematode S. oscari, is considered to be a host generalist (i.e. parasitizing many host species), with a heteroxenic life cycle with arthropods as intermediate hosts (Barreto-Lima \& Anjos, 2014), and is a common parasite of lizards of the genus Tropidurus (Ávila \& Silva, 2010), having been found in T. guarani, T. spinulosus, T. torquatus, T. melanopleurus and T. hispidus (Bursey \& Goldberg, 2004; Ávila \& Silva, 2010; Brito et al., 2014). Moreover, S. oscari is known to infect lizards of other taxa, such as Ameiva ameiva, Anolis fuscoauratus, A. punctatus, $A$. transversalis, Enyalius bilineatus, Eurolophosaurus nanuzae, Brasiliscincus agilis, Plica plica and P. umbra (Fontes et al., 2003; Ávila \& Silva, 2010; Barreto-Lima \& Anjos, 2014). The third parasite species found, Physaloptera sp., is known to parasitize A. ameiva, Glaucomastix littoralis, Ameivula ocellifera, H. mabouia, B. agilis, Psychosaura macrorhyncha, Polychrus acutirostris, Tropidurus etheridgei, T. torquatus, T. hispidus, Salvator meriane and Tupinambis teguixin (Ávila \& Silva, 2010; Ávila et al., 2012; Pereira et al., 2012). Therefore, the component community of helminths parasitizing the lizard T. montanus can be considered to be comprised of host generalist parasites, and our record extends hosts species for P. alvarengai and S. oscari.

The component community of parasites of $T$. montanus is species poor when compared to those found for other species of the genus (e.g. T. torquatus (Pereira et al., 2012), T. hispidus (Brito et al., 2014; Galdino et al., 2014) and T. semitaeniatus (Brito et al., 2014, Bezerra et al., 2015)). The high-elevation formations of the mountains from eastern Brazil, such as the rocky outcrops from the highlands of the Espinhaço Range, are considered to be an archipelago of isolated insular mountaintop habitats (e.g. Chaves et al., 2015). Therefore, the insularity of the mountaintop rocky outcrops of the Serra da Piedade is remarkable as this mountain is apart from the main Espinhaço Mountain Range where T. montanus is distributed. The helminth fauna of hosts inhabiting insular environments can be expected to be poorer than those parasitizing hosts on the mainland (e.g. Dobson et al., 1992). For example, the pattern of helminths infecting rodent species differed between insular and continental populations, with insular populations having lower helminth richness (Kuhnen et al., 2012). The same pattern seems to hold true for lizards, with species-poor helminth infracommunities being found on hosts from insular environments (Dobson et al., 1992; Martin \& Roca, 2005). Therefore, the insular nature of the sampled area might constrain the available pool of helminth species that can infect individuals of T. montanus.

We found no intersexual difference in overall parasite prevalence. Intersexual differences in parasite prevalence are generally related to distinct social roles of male and female lizards, which in turn are associated with unequal blood hormone levels (Fuxjager et al., 2011; see also Anjos et al., 2012). Males of T. montanus use larger home ranges than females (Galdino et al., in prep.), which is a proxy for different social roles between the sexes. Thus, one might expect that the use of larger areas by males might expose them to greater chances of infection, at least by $P$. alvarengai, a monoxenous parasite species. Therefore, our results cannot be explained by the different social role and/or space use of males and females of $T$. montanus. Concerning heteroxenous parasites, we regarded the similarities in prevalence between the sexes as being due to a broad diet overlap between males and females, as shown by Kiefer (1998). Therefore, the similarity in overall prevalence of $S$. oscari between the sexes might be related to males and females having the same dietary patterns.

We did not find any relationship between $T$. montanus body size and intensity of infection of either $P$. alvarengai or S. oscari. It is argued that hosts with a larger body size would provide more space for helminths to colonize, thereby leading to a positive relationship between the two variables (Poulin, 1997; Ribas et al., 1998). It is also suggested that changes in infection intensity with size will be related to ontogenetic changes in diet (Fontes et al., 2003). In the case of T. montanus, young and adult lizards have similar diets, and so the non-relationship between intensity of infection and lizard body size might be associated with ontogenetic conservatism in diet, which in turn might expose both young and adults to the same chances of infection. A relationship between lizard body size and intensity of infection was not found for other species of lizards (e.g. T. torquatus and Brasiliscincus (former Mabuya) agilis (Van Sluys et al., 1997), T. hispidus (Galdino et al., 2014) and T. semitaeniatus (Bezerra et al., 2015)), suggesting that, in general, there is no trend between body size and intensity of infection for lizards.

Our results indicated that some patterns of helminth infection in lizards may vary seasonally. We found that the proportion of infected hosts was higher during the dry period than during the rainy period. Seasonal variation in helminth infection patterns has also been found for the Neotropical T. torquatus, with larger overall intensity of infection during the dry period (Pereira et al., 2012). In the case of $T$. torquatus, Pereira et al. (2012) suggested that interseasonal differences in overall intensity of infection might be related to the consumption of a plant species with anthelmintic compounds. Although T. montanus increases its consumption of plant material during the dry period (Kiefer, 1998), we are not able to relate the observed seasonal variation in overall helminth intensity directly to plant ingestion. Alternatively, as the diet composition of $T$. montanus varies seasonally (Kiefer, 1998), the observed change in overall prevalence in our 
study might be related to seasonal changes in the types of ingested food items.

\section{Acknowledgements}

We are grateful to the administrative staff of Santuário Estadual Nossa Senhora da Piedade for the permit to work in the area. We thank M.J. Goulart, C.M. de Oliveira, L.K. Pereira, L.H.A. Glauss and C.C. Lisboa for their kind help during the fieldwork. We thank E. Wild for the English language review. C.A.B.G. and L.B.N. thank Instituto Chico Mendes (ICMBio) for the permit to collect the animals.

\section{Financial support}

A.B.H.P.V. thanks the Programa de Educação Tutorial/ Ministério da Educação/Secretaria de Ensino Superior for grant funding. L.A.A. is thankful to Fundação de Amparo à Pesquisa do Estado de São Paulo (FAPESP, process no. 2012/20978-2) for grant funding. L.B.N. thanks Fundação de Amparo à Pesquisa do Estado de Minas Gerais (FAPEMIG, processes CRA APQ-00683-12 and CRA APQ-02067-14); Fundo de Incentivo à Pesquisa (FIP/PUC Minas) and the Conselho Nacional de Desenvolvimento Científico e Tecnológico $(\mathrm{CNPq}$, process 479457/2012-3) for financial support.

\section{Conflict of interest}

None.

\section{Ethical standards}

We followed the Guidelines for the Euthanasia of Animals (2013) of the American Veterinary Medical Association for euthanizing the lizards. The Instituto Chico Mendes de Conservação da Biodiversidade issued the permits (SisBio 35541 and 37266-3) to collect the animals.

\section{References}

Altizer, S., Dobson, A., Hosseini, P., Hudson, P., Pascual, M. \& Rohani, P. (2006) Seasonality and the dynamics of infectious diseases. Ecology Letters 9, 467484.

Alvares, C.A., Stape, J.L., Sentelhas, P.C., Moraes, J.L.G. \& Sparovek, G. (2014) Koppen's climate classification map for Brazil. Meteorologische Zeitschrift 22, 711-728.

Andrade, C. (2000) Meios e soluções comumente empregados em laboratórios. 1st edn. 353 pp. Seropédica, Bazil, UFRRJ.

Anjos, L.A., Bezerra, C.H., Passos, D.C., Zanchi, D. \& Galdino, C.A.B. (2011) Helminth fauna of two gecko lizards, Hemidactylus agrius and Lygodactylus klugei (Gekkonidae), from caatinga biome, northeastern Brazil. Neotropical Helminthology 5, 285-290.

Anjos, L.A., Ávila, R.W., Ribeiro, S.C., Almeida, W.O. \& Silva, R.J. (2012) Gastrointestinal nematodes of the lizard Tropidurus hispidus (Squamata: Tropiduridae) from a semi-arid region of north-eastern Brazil. Journal of Helminthology 87, 443-449.
Ávila, R.W. \& Silva, R. (2010) Checklist of helminths from lizards and amphisbaenians (Reptilia, Squamata) of South America. Journal of Venomous Animals and Toxins Including Tropical Diseases 16, 543-572.

Ávila, R.W., Cardoso, M.W., Oda, F.H. \& Silva, R.J. (2011) Helminths from lizards (Reptilia: Squamata) at the Cerrado of Goiás State, Brazil. Comparative Parasitology 78, 120-128.

Ávila, R.W., Anjos, L.A., Ribeiro, S.C., Morais, D.H., Silva, R.J. \& Almeida, W.O. (2012) Nematodes of lizards (Reptilia: Squamata) from Caatinga Biome, Northeastern Brazil. Comparative Parasitology 79, 56-63.

Barreto-Lima, A.F. \& Anjos, L.A. (2014) Occurrence of Strongyluris oscari (Nematoda; Heterakidae) in Enyalius bilineatus (Squamata: Leiosauridae) from the Brazilian Atlantic Forest. Herpetology Notes 7, 455-456.

Bezerra, C.H., Ávila, R.W., Passos, D.C., Zanchi-Silva, D. \& Galdino, C.B.A. (2015) Levels of helminth infection in the flat lizard Tropidurus semitaeniatus from northeastern Brazil. Journal of Helminthology. doi:10.1017/ S0022149X15000826.

Bezerra, C.H., Pinheiro, L.T., Melo, G.C., Zanchi-Silva, D., Queiroz, M.S., Anjos, L.A., Harris, D. \& Borges-Nojosa, M. (2016) Assessing the influence of geographic distance in parasite communities of an exotic lizard. Acta Parasitologica 61, 136-143.

Brito, S.V., Ferreira, F.S., Ribeiro, S.C., Anjos, L.A., Almeida, W.O., Mesquita, D.O. \& Vasconcellos, A. (2014) Spatial-temporal variation of parasites in Cnemidophorus ocellifer (Teiidae) and Tropidurus hispidus and Tropidurus semitaeniatus (Tropiduridae) from Caatinga areas in northeastern Brazil. Parasitology Research 113, 1163-1169.

Bursey, C.R. \& Goldberg, S.R. (2004) Helminths of Tropidurus guarani (Sauria: Tropiduridae) from Paraguay. Comparative Parasitology 71, 203-207.

Bush, A.O., Lafferty, K.D., Lotz, J.M. \& Shostak, A.W. (1997) Parasitology meets ecology on its own terms: Margolis et al. revisited. Journal of Parasitology 83, 575583.

Chaves, A.V., Freitas, G.H.S., Vasconcelos, M.F. \& Santos, F.R. (2015) Biogeographic patterns, origin and speciation of the endemic birds from eastern Brazilian mountaintops: a review. Systematics and Biodiversity 13, $1-16$.

Dobson, A.P., Pacala, S.W., Roughgarden, J.D., Carper, E.R. \& Harris, E.A. (1992) The parasites of Anolis lizards in the northern Lesser Antilles. I. Patterns of distribution and abundance. Oecologia 91, 110-117.

Filogonio, R., Del Lama, F.S., Machado, L.L., Drumond, M., Zanon, I., Mezzetti, N.A. \& Galdino, C.A.B. (2010) Daily activity and microhabitat use of sympatric lizards from Serra do Cipó, southeastern Brazil. Iheringia, Série Zoologia 100, 336-340.

Fontes, A.F., Vicente, J.J., Kiefer, M.C. \& Van Sluys, M. (2003) Parasitism by helminths in Eurolophosaurus nanuzae (Lacertilia: Tropiduridae) in an area of rocky outcrops in Minas Gerais State, Southeastern Brazil. Journal of Herpetology 37, 736-741.

Fuxjager, M.J., Foufopoulos, J., Diaz-Uriarte, R. \& Marler, C.A. (2011) Functionally opposing effects of testosterone on two different types of parasite: 
implications for the immunocompetence handicap hypothesis. Functional Ecology 25, 132-138.

Galdino, C.A.B., Ávila, R.W., Bezerra, C.H., Passos, D. C., Melo, G.C. \& Zanchi-Silva, D. (2014) Helminth infection patterns in a lizard (Tropidurus hispidus) population from a semiarid Neotropical area: associations between female reproductive allocation and parasite loads. Journal of Parasitology 100, 864-867.

Goldberg, S.R. \& Bursey, C.R. (2012) Endohelminths of the Socorro Island Tree Lizard, Urosaurus auriculatus (Squamata: Phrynosomatidae), from Colima, Mexico. Comparative Parasitology 79, 269-274.

Hatano, F.H., Vrcibradic, D., Galdino, C.A.B., Cunha-Barros, M., Rocha, C.F.D \& Van Sluys, M. (2001) Thermal ecology and activity patterns of the lizard community of the restinga of Jurubatiba, Macaé, RJ. Revista Brasileira de Biologia 61, 287-294.

Hothorn, T., Hornik, K., van de Wiel, M.A. \& Zeileis, A. (2008) Implementing a class of permutation tests: the Coin package. Journal of Statistical Software 28, 1-23.

Kiefer, M.C. (1998) Dieta, modo de forrageamentoe uso do microhábitat em duas espécies simpátricas de Tropidurus (Sauria, Tropiduridae) na Serra do Cipó, Minas Gerais. Master's Dissertation, UNICAMP, Campinas, Brazil.

Kuhnen, V.V., Graipel, M.E. \& Pinto, C.J.C. (2012) Differences in richness and composition of gastrointestinal parasites of small rodents (Cricetidae, Rodentia) in a continental and insular area of the Atlantic Forest in Santa Catarina state, Brazil. Brazilian Journal of Biology 72, 563-567.

Lambertz, M., Kohlsdorf, T., Perry, S.F., Ávila, R.W. \& Silva, R.J. (2012) First assessment of the endoparasitic nematode fauna of four psammophilous species of Tropiduridae (Squamata: Iguania) endemic to northeastern Brazil. Acta Herpetologica 7, 315-323.

Lunaschi, L.I., Lamas, M.F. \& Drago, F.B. (2012) A new species of Mathevotaenia (Cestoda, Anoplocephalidae) parasitizing Tropidurus spinulosus (Reptilia, Squamata) from northeastern Argentina. Revista Mexicana de Biodiversidad 83, 583-590.

Martin, J.E. \& Roca, V. (2005) Helminths of the Atlantic lizard, Gallotia atlantica (Reptilia, Lacertidae), in the Canary Islands (Eastern Atlantic): composition and structure of component communities. Acta Parasitologica 50, 85-89.

Neves, A.C.O., Barbieri, A.F., Pacheco, A.A., Resende, F. M., Braga, R.F., Azevedo, A.A. \& Fernandes, G.W. (2016) The human dimension in the Espinhaço
Mountains: land conversion and ecosystem services. pp. 501-526 in Fernandes, G.W. (Ed.) Ecology and conservation of mountaintop grasslands in Brazil. Switzerland, Springer.

Padilha, T.N. \& Duarte, M.J.F. (1979) Ocorrência de Parapharyngodon alvarengai Freitas, 1957, em Ameiva ameiva (L.) no estado do Rio de Janeiro (Nematoda, Oxyuroidea). Atas da Sociedade de Biologia do Rio de Janeiro 20, 21-22.

Pereira, F.B., Sousa, B.M. \& Lima, S.S. (2012) Helminth community structure of Tropidurus torquatus (Squamata: Tropiduridae) in a rocky outcrop area of Minas Gerais state, southeastern Brazil. Journal of Parasitology 98, 6-10.

Poulin, R. (1997) Species richness of parasite assemblages: evolution and patterns. Annual Review in Ecology and Systematics 28, 341-358.

Ribas, S.C., Rocha, C.F.D., Teixeira-Filho, P.F. \& Vicente, J.J. (1995) Helminths (Nematoda) of the lizard Cnemidophorus ocellifer (Sauria: Teiidae): assessing the effect of rainfall, body size and sex in the nematode infection rates. Journal of Brazilian Association for the Advancement of Science 47, 88-91.

Ribas, S.C., Rocha, C.F.D., Teixeira-Filho, P.F. \& Vicente, J.J. (1998) Nematode infection in two sympatric lizards (Tropidurus torquatus and Ameiva ameiva) with different foraging tactics. Amphibia-Reptilia 19, 323-330.

Rodrigues, M.T. (1987) Sistematica, ecologia e zoogeografia dos Tropidurus do grupo torquatus ao sul do Rio Amazonas (Sauria, Iguanidae). Arquivos de Zoologia 31, 105-230.

Santos, J.N., Melo, F.T.V., Nazaré, L.C., Furtado, A.P. \& Giese, E.G. (2013) Strongyluris amazonicus n. sp. (Nematoda: Heterakidae): a parasite of Tropidurus oreadicus from the Brazilian Amazon. Acta Tropica 128, 96-102.

Uetz, P. \& Hošek, J. (Eds). (2016) The reptile database. Available at http://www.reptile-database.org (accessed 20 June 2016).

Van Sluys, M., Rocha, C.F.D., Bergallo, H.G., Vrcibradic, D. \& Ribas, S.C. (1997) Nematode infection in three sympatric lizards in an isolated fragment of restinga habitat in southeastern Brazil. Amphibia-Reptilia 18, 442-446.

Vrcibradic, D., Rocha, C.F.D., Ribas, S.C. \& Vicente, J.J. (1999) Nematodes infecting the skink Mabuya frenata in Valinhos, São Paulo State, southeastern Brazil. Amphibia-Reptilia 20, 333-339. 